\title{
The Values of Character in Early Childhood PAUD Nurut-Taqwa South Sangatta East Borneo
}

\author{
Budi Rahardjo \\ Magister of Early Childhood Education \\ Mulawarman University \\ Samarinda, Indonesia \\ rahardjobudi11@yahoo.com
}

\author{
Nasimul Husniyah \\ Magister of Early Childhood Education \\ Mulawarman University \\ Samarinda, Indonesia \\ pgpaudmulawarman@gmail.com
}

\begin{abstract}
The objectives of the research are (1) to analyze the teaching system what is used a storytelling method on developing early-years students character (2) to describe a storytelling method, (3) to describe the development of character values of 45 years old early-years students'. The method which was used in collecting data are: (1) participative observation method, (2) Interview (3) Documentation. The result of the research shows that (1) Exemplary attitudes made by the teacher in all activities can foster the values of positive characters in children, (2) Through the storytelling method using the image media, the character values can grow as expected, (3) cohesiveness and cooperation has been well established between children and teachers. The conclusion from the research that the activities of teachers in storytelling methods can develop the values of child characteristics such as the value of honesty, discipline, confidence and responsibility.
\end{abstract}

Keywords - values, character, early-year students

\section{INTRODUCTION}

Early childhood education is a coaching effort aimed at children from birth up to the age of six that is done through the provision of educational stimuli to assist growth and physical and spiritual development so that children have readiness in entering further education.

In response to the development of early childhood, the need for an educational program designed in accordance with the level of child development. It has its own world and characteristics that are much different from adults. Character education is a term that increasingly gets recognition from the people of Indonesia. The Indonesian nation consciously builds education based on noble akhlaq.

As former President of Indonesia, Bung Karno once said, "This nation must be built by prioritizing character building because character building will make Indonesia a great nation, advanced and glorious, and dignified. If this character building is not done, the nation of Indonesia will become the coolie nation. "

With the education of a child's character will be emotionally intelligent. Emotional intelligence is an important provision in preparing children for the future because a child will succeed in facing obstacles that exist in front of him.

Referring to the characteristics of the 2013 curriculum, Early Childhood Education is designed with characteristics one of which is to optimize child development which includes: religious and moral values, physical-motor, cognitive, language, emotional, and art aspects as reflected in the balance of competence of attitude, and skills but it is unfortunate that the planting of character values in early childhood has not been optimally developed by teachers in the PAUD Nurut-Taqwa Sangatta Selatan Kutai Timur.

Character education should be done from an early age, ie age 0-6 years. Because early age is a golden age of development (golden age) whose success is the very decisive quality of children in adulthood. Montessori calls it the sensitivity period [1]. If this stage can be optimized by providing a variety of productive stimulation, then the development of children in adulthood will also take place productively.

From some of the above opinions, it is very important to conduct research on the development of teacher activity and values of early childhood characters through the method of storytelling in early childhood Nurut-Taqwa East Kutai District. In the learning process conducted in early childhood, Nurut-taqwa educators have difficulty in applying character education to children. Because after being investigated other than children have an inappropriate background and parenting patterns, their parents also have a low education and less understanding about the pattern of care is good and right.

In addition to the attitude and behavior of children is not reflect on the values of the characters, especially children lack confidence, less responsible, less disciplined and lying. This happens because the teacher's role in teaching is not maximal, the teacher's way of giving the exemplary example is inappropriate, and the role of the parent in giving a good exemplary example to the children is very less so that the child's behavior is far from positive character values.

Therefore, researchers conduct research with storytelling method in developing the values of the characters in early childhood. With storytelling method using image media expected the development of teacher activity and character values will develop well.

Departing from the context of the research above, then the formulation of this research problem is as follows: (1) How the teacher activity in developing the character values of children aged 4-5 years through the method of storytelling in Early Childhood Nurut-Taqwa Sangatta South Kutai? (2) How is the student activity in teaching using storytelling method in developing the values of the character of 4-5 years old children in the Nurut-Taqwa Anak Sangatta Selatan Kutai Timur? (3) How is the development of the values of the characters of children aged 4-5 years in early childhood Nurut-Taqwa Sangatta South Kutai Timur?

With the aim to know the following: (1) To analyze the teaching of teachers using storytelling method in developing 
the values of the character of children aged 4-5 years in Early Childhood Nurut-Taqwa Sangatta South Kutai. (2) To describe the activity of students in teaching using storytelling method in developing the values of the character of children aged 4-5 years in early childhood Nurut-Taqwa Sangatta South Kutai Timur. (3) To describe the development of the values of the characters of children aged 4-5 years in the Nurut-Taqwa Sangatta Southern Kutai Timur.

\section{METHOD}

In this research used qualitative approach research method. The qualitative approach is a way of thinking researchers to classify research type according to the method [2]. Descriptive research is basically aimed at giving an idea of what is happening in the field in accordance with actual reality. It uses interview and observation techniques as a data collection procedure.

While this type of study is a case study that is defined as a limited system exploration of one or more cases through detailed and in-depth data collection, including rich sources of information in context [3]. The case study as a system gives the meaning of each case is a whole consisting of a substantial component of substance and context. Data used in this research are primary data and secondary data.

Primary data in this research is direct data obtained from related informants in (1) teacher activity in developing the values of the character of early child 4-5 years through the method of storytelling in early childhood Nurut-Taqwa Sangatta South Kutai in 2016. (2) student activity in teaching using storytelling method in PAUD Nurut-Taqwa Sangatta Selatan Regency of East Kutai 2016. (3) the development of character values of children aged 4-5 years in early childhood Nurut-Taqwa Sangatta South East Kutai Regency in 2017.

Primary data were obtained from participant observation and in-depth interviews. Secondary data is processed data already available at research location. The processed data is the documentation data needed for the PAUD Nurut-Taqwa Sangatta South East Kutai Regency in 2017. Sources of data in this study are (1) Head of PAUD Nurut-Taqwa Sangatta Selatan Kutai Timur, (2) PAUD Teachers Nurut-Taqwa Sangatta Selatan Kutai Timur, (3) Students of PAUD NurutTaqwa Kecamatan Sangatta Selatan of East Kutai Regency.

Methods used in data collection include: (a) direct observation method (direct observation), participatory observation, as the primary method for collecting data on the development of the values of early childhood characters, (b) the method of in-depth interview (circumstantial interview) conducted on the PAUD Head, teachers, and students, (c) method of documentation, as a method of supporting to obtain data / facts in the field.

Data analysis techniques used in the following stages: First data taken from several sources, can be from observations, field notes, and interviews are classified according to each characteristic. Data from the recording is transcribed and grouped. Second, the transcribed and grouped data are then analyzed using flow model analysis stages, starting with: (1) data reduction, (2) data presentation, (3) conclusion and verification [4].

Examination and Data Checking (Triangulation) to ensure the reliability of the data obtained in this study, the researchers checked the validity of the findings (data) or validity test of four criteria, suggested by Moleong namely: (1) trust (credibility); (2) transparency (transferability), (3) dependability, and (4) confirmability [5].

\section{RESUlT AND DisCUSSION}

By using Huberman and Miles data theory by reducing data that is collected data is taken data in accordance with the formulation of the problem so as to reach a conclusion. Giving meaning to the results of research based on interpretation of data description of research results and its relation to the theoretical framework with a view to facilitate describe, explain and interpret data in taking conclusions. The following discussion covers:

\section{A. The Activity of Teachers in Developing the Character Values of Children Aged 4-5 Years in PAUD Nurut- Taqwa}

Based on the things that are encountered at the time of the study took place as has been described, it can be concluded that in the development of the values of the character of children in the PAUD Nurut taqwa through the method of storytelling and exemplary example of the teacher that is welcoming to the time the child comes home. By telling the story of positive characters and equipped with media images will make it easier for children to understand and understand the positive and negative characters. While exemplary is the attitude that is exemplified by the teacher both with good deeds and good manners done by the teacher.

Performance teachers give a special impression to children at the time of welcoming children with attitude and polite words and attention and hospitality to make children comfortable at school. Performance teacher in reading the story so that children focus, this moment is used by teachers in conveying the values of positive characters and learning objectives that day [6].

The approach used by teachers with the flow of constructivism is one of the schools of cognitive psychology that believe that learning is building knowledge itself, after digestion and then understood in the individual[7]. This knowledge is recreated and built from within a person through his observation, experience, and understanding. With the storytelling method, we can enter the child's world because of the child's own imaginative characteristics, which makes the child's emotional involvement

\section{B. An Activity of Pupils in Teaching Using Storytelling Method in Developing Character Values of Children Aged 4-5 Years in Early Childhood Nurut-Taqwa}

Honesty: From the theory and the results of the research that has been done by the author shows that by giving exemplary attitudes both in words and deeds of honesty character values through habituation in all activities, then the children will get used to saying the truth well and wisely.

Responsibilities: Thus the sense of responsibility of the child has been well planted that is when in some practice congregational prayers, rituals of pilgrims, ablution practice and queuing hand washing even in the learning activities of all centers.

Children are very disciplined follow the culture queue in these activities although sometimes there are not yet orderly 
but they are directly responsible and forgive each other when there is a dispute, like a child who stepped on the foot or happened to encourage each other. Behavioral responsibility is used by the child in every activity. Because the activities provided by the teacher to the child are all fun, so the child is interested in doing so.

From the research that writers do about the discipline and believe in self and from the above theoretical opinion, the authors can conclude that by inculcating the attitude of discipline and self-confidence through attitude, words, and story in front of the child about the pillars of the appropriate character with an example of discipline and self-confidence, the writer believes that the child is capable of doing things without hesitation, Likes to try new things even though it is difficult and not afraid to fail, the child will regard failure as a challenge to keep trying and trying to learn from mistakes and keep trying to be better, the child is able to know the strengths and weaknesses of the self, proud of what is owned and willing to accept criticism [8].

\section{The Development of Character Values of Children Aged 4-5 Years in Early Childhood Nurut-Taqwa Sangatta Selatan East Kutai Regency}

From the result of observation to the students of A group of PAUD Nurut-Taqwa, there is one child who still needs strengthening in patience (managing emotions), playing safe. In practice, the teacher develops the character values that children need according to the current situation. The multiplicity of emphasis on the value of this character will enrich the child towards the development of character intelligence in children, required the same consistent teachers and consistency by each teacher to make the rules. The child will find that in any area of the school there are rules.

The observation of 8 children of Group A was started from August to October 2017. Observations were made when the children were in the room in learning both in the room and outside the classroom.

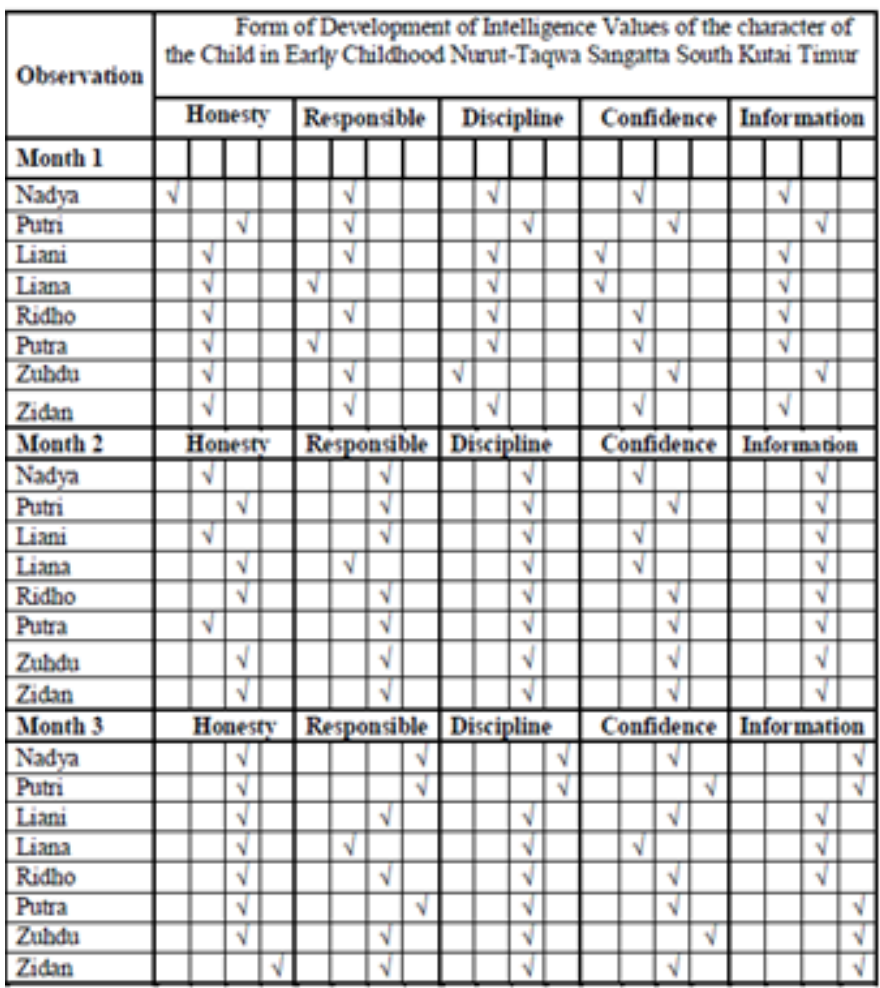

Fig. 1. Observation Results on Intellegence Character Values of The Character of Children in Early Childhood Nurut-Taqwa Sangatta South Kutai Timur.

Fig. 1. shows the observation results on intellegence character values of the character of children in early childhood Nurut-Taqwa Sangatta South Kutai Timur. From the picture, it can be seen that all of the chidren show the development of intellegence value of character for 3 months respectively.

Analysis in general, 4 character values observed at the time of learning in school from the beginning of learning to the end and activities at the Sentra shows that the intelligence values of children's character group A PAUD Nurut Taqwa Sangatta Selatan East Kutai Regency is mostly developed according to expectations (BSH), and some are very well developed (BSB). This can be seen clearly in the Recapitulation of Output Observations for 3 months in a row. From the above description can be concluded that the development of intelligence values of children character of group A, in general, have developed as expected / good (BSH). In the meantime, it requires consistency of teachers in upholding the footing and rules in the classroom or outside the classroom. Teachers are the ultimate example of changing the development of a child's character because a teacher is an idol for a child that will always be imitated in any case.

\section{CONCLUSION}

The activity of teachers in developing the values of the character of children aged 4-5 years through the method of storytelling in early childhood Nurut-taqwa very wise in providing the exemplary example of attitude and practice directly in front of children, anytime, anywhere, especially in the character indicator of discipline, honesty, independence, And Responsibility. Consistent teachers and the school in applying the values of character is one key to the successful application of character values in children.

The activity of students in teaching using storytelling method in developing the values of the character of children aged 4-5 years in early child Nuruttaqwa run smoothly in accordance with the learning program that has been compiled in the semester program and the application of the character value that has been determined. With the story-telling method children can more easily understand and follow the positive characters that have been exemplified through the media images when the teacher tells stories, as well as direct examples done by teachers in all learning activities in school.

The development of intelligence values of children character of group A, in general, has developed as expected / good (BSH). This can be seen from the observation sheet for the development of children's character values that have been done for 3 months. The consistency of teachers in enforcing the footing and rules in the classroom or outside the class becomes a benchmark for the success of children's education. Teachers are the ultimate example of changing the development of a child's character because a teacher is an idol for a child that will always be imitated in any case.

\section{REFERENCES}

[1] Montesori Maris (2013), Metode Montessori, Yogyakarta: Pustaka Pelajar Yogyakarta 
[2] Suharsimi Arikunto, Prosedur Penelitian Suatu Pendekatan Praktik, Jakarta, Rineka Cipta, 2010. H.39

[3] Robert K. Yin (2013), Case Study Research: Design and Methods (terjemahan M. Djauzi Mudzakir). (Jakarta: Grafindo Persada).

[4] Milles, Matthew. A. Michael Huberman, Analisis Data Kualitatif, Cetakan I, VI, Pres, Jakarta, 2010. H.16

[5] Moleong J. Lexy, Metodologi Penelitian Kualitatif, Edisi Revisi, Jakarta, PT. Remaja Rosdakarya Bandung, 2008, h. 6
[6] Rahardjo, Budi (2009). Optimalisasi Kecerdasan Anak Usia Dini di TK dan keluarga A E Taqwa Rawamangun, Jakarta Timur Pasca Sarjana Universitas Negeri Jakarta

[7] Robert J.Sternberg (2008), Pisikologi Kognitif, Yogyakarta: Pustaka Pelajar Yogyakarta

[8] Megawangi, Ratna (2010). Pengembangan Program Pendidikan Karakter di Sekolah, Jakarta; Pengalaman Sekolah Karakter. Makalah. IHF 